\title{
E-Module of Chemistry Practicum Based on Cooperative Learning on Salt Hydrolysis Material to Improve Students' Scientific Literacy
}

\author{
Airiza Dian Luthfiana, * Rusly Hidayah \\ Chemistry Department, Faculty of Mathematics and Science, Universitas Negeri Surabaya, \\ Ketintang Campus, Surabaya, 60231, Indonesia \\ *Corresponding Author e-mail: ruslyhidayah@unesa.ac.id
}

Received: January 2022; Revised: January 2022; Published: January 2022

\begin{abstract}
This research aimed to determine the feasibility of the practicum e-module based on cooperative learning on salt hydrolysisi material. Feasibility can be viewed from the validity, practicality, and effectiveness. This research was carried out in class XII MIA 1 at SMAM 10 GKB with a total of 24 students. The research method used is the 4-D method. This study used instruments in the form of validation sheets, student response questionnaires, and pretest posttest question sheets. To analyze the results of the scientific literacy test, a non parameteric test was used (Wilcoxon Test). The validity of the e-module has valid and very valid criteria, the content criteria obtained a percentage of $81.37 \%$, language criteria obtained $83.33 \%$, presentation criteria obtained $80.66 \%$, and graphics criteria obtained $82.66 \%$. Based on practicality, the content criteria obtained a response percentage of $87.33 \%$, the presentation criteria obtained $86.78 \%$, the graphic criteria obtained $97.50 \%$, and the language criteria obtained $97.52 \%$. Student activities have very practical criteria, because the percentage is $100 \%$ or it can be stated that all activities are carried out. Wilcoxon test results get the Asymp value. Sig. (2-tailed) of $0.000\left(\mathrm{H}_{0}\right.$ is rejected). E-module of chemistry practicum based on cooperative learning on salt hydrolysis material can increase students' scientific literacy results so that it is effective to use.
\end{abstract}

Keywords: practicum e-module, cooperative learning, salt hydrolysis, scientific literacy

How to Cite: Luthfiana, A., \& Hidayah, R. (2022). E-Module of Chemistry Practicum Based on Cooperative Learning on Salt Hydrolysis Material to Improve Students' Scientific Literacy. Prisma Sains : Jurnal Pengkajian Ilmu dan Pembelajaran Matematika dan IPA IKIP Mataram, 10(1), 36-47. doi:https://doi.org/10.33394/j-ps.v10i1.4763

https://doi.org/10.33394/j-ps.v10i1.4763

\section{INTRODUCTION}

In chemistry learning students will do several things such as observing, collecting information, asking questions, reasoning/associating, and communicating a finding from the results of analysis. Thus, students will gain knowledge as well as improve direct skills (Mohandas, 2014). Practicum can build students' understanding by focusing on direct experience (Djamarah \& Zain, 2006). Practicum learning is the right method to improve students' understanding of an abstract concept. Practicum learning will increase students' curiosity so that it can affect their learning outcomes (Harefa et al., 2019). In addition, the practicum method can be a creative forum for teachers in facilitating learning so that student can explore the concepts that are not yet understood theoretically through a practicum (Waris et al., 2017).

One of the important components of practicum learning is a practicum module. The development of science and technology makes the learning process interesting and fun, such as the existence of a practicum e-module. In addition, due to the pandemic, online learning caused the need for innovation in devices or facilities to support online learning activities. Utilizing technology and mastering technology are the teacher's competence required to 
rapidly increase in dealing with online learning (Purwanto et al., 2020). Interactive electronic modules will involve students' sensory activities, provide opportunities for students to determine the acceleration of their learning, provide direct feedback and make students conduct self-evaluations (Yulando, 2019).

E-module is a collection of information that looks and has format similar to a book. Emodule is presented in electronic media to be read through a computer, laptop or another gadget. The difference between the print module and the electronic module is in the physical presentation format. In general, components in electronic modules are adaptations of several components available in print modules (Wibowo, 2018). Practicum e-modules can be meaningful as electronic teaching materials that can help students understand concepts in practicum implementation.

According to the 2013 curriculum, learning should not maintain the old paradigm, namely making the teacher as the center of learning. Teacher center learning is still widely applied in classroom because these learning is practical and does not take up much time. To improve the problems above, it can be started by increasing the competence of the teachers, either in delivering the material, in using appropriate teaching methods and techniques, or in using methods that suit the needs of students (Noviana \& Huda, 2020).

Cooperative learning is a learning model by forming small groups whose members are heterogeneous to work as a team to solve problem, tasks, or do something to achieve common goals (Hayati, 2017). The typical form of cooperative learning is Student Team Achievement Divisions (STAD), a method of solving problems in groups and motivating students to be more active in learning. STAD is one of the simplest cooperative learning methods, so it is considered a good model when teachers want to implement cooperative learning for the first time. STAD helps promote cooperative learning and self-control skills (Kim, 2018).

Chemistry learning requires students to be able to understand concepts correctly, it means there are no misconceptions and not just solving problems. The occurrence of misconceptions causes students to have difficulty in learning other related concepts such as the salt hydrolysis material with a buffer solution and acid base materials. The results of Wiyono's research (2011) show that in studying the concept of salt hydrolysis, it is necessary to understand the correct Bronsted-Lowry acid-base concept (Wiyono, 2011). One of the conceptual errors experienced by students in studying salt hydrolysis material is converting the unit volume of solution into liters which can affect the calculation of determining the mass of salt (Febriani et al., 2018). In Acids, Bases, and Salts, it is highly recommended to carry out practicum learning in the laboratory so that students' learning mastery can be achieved (Hidayah \& Luthfi, 2017).

Based on the 2018 OECD measurement results, it can be seen that the ranking of the Program for International Student Assessment (PISA) Indonesia is at the bottom (Kasih, 2020). The low scientific literacy of students in Indonesia can be influenced by several factors: the suitability of the curriculum with the teaching model by the teacher and the lack of direct environmental involvement in learning activities. Individuals who are scientifically literate or have high scientific literacy will have a comfortable, competent, and confident spirit towards scientific, technical and artifact problems (Choi et al., 2011).

This is in line with the preliminary study at SMAM 10 GKB which showed that the low category dominated the scientific literacy ability achieved by students. The percentage of scientific literacy skills in the high category is $0.0 \%$, the percentage in the medium category is $10 \%$, and the percentage in the low category is $90 \%$. While the scientific literacy skill in the context aspect is $37.23 \%$, the content knowledge aspect is $6.3 \%$ and the competence aspect is $30 \%$. The largest score obtained by the students was 38 with an average score was 20.4 . 
The results of interviews with chemistry teachers at SMAM 10 GKB indicate that there is support for scientific literacy skills training because it is very important for students. In improving scientific literacy, students need to be trained in text questions that contain scientific phenomena. It requires students to study well in order to be able to answer problems in phenomena (Merta et al., 2020). In addition, with the problem-solving process in the practicum, students carry out a series of scientific activities such as identifying variables, creating data tables, describing relationships between variables, obtaining and processing data, analyzing observations and making hypotheses (Rosmalinda et al., 2013).

Vogelzang (2020) states that students need to learn how to discuss science, environment, and industry issues. The development of society towards greater complexity requires students to develop their scientific literacy. Therefore, it is recommended for students to acquire substantial scientific knowledge as well as develop appropriate skills to deal with complex problems. These abilities enable students to participate in making decision in society. Innovations in teaching strategies can help students become scientifically literate citizens (Vogelzang et al., 2020).

Regarding practicum learning, the teacher explained that practicum could not be carried out routinely on any material that allowed for a practicum due to limited tools and materials. Practicum had previously been carried out on the salt hydrolysis material before the pandemic. During the pandemic, practicum was never carried out, but as an alternative the teacher provided practicum videos or experiments that were analyzed or discussed together with students. The form of the practicum report is as simple as a worksheet that contains practical procedures and a simple report format. The obstacle faced during the practicum is the seriousness of the students who are still lacking in carrying out the practicum. But the problem is quite easy for teachers to overcome.

Practicum e-module based on cooperative is a module that can be accessed online and aims to increase scientific literacy. Students' scientific literacy is trained through identifying problems, formulating hypotheses, designing experimental procedures, analyzing experimental results, concluding experimental results, applying experimental results in everyday life, and answering several questions related to everyday life. In addition, this module is used in groups so that there is an exchange of ideas and stimulates the spirit of learning between students. This module was developed on salt hydrolysis material and is expected to help students learn independently with a little help from the teacher. Students are trained to find their own concepts through a discussion with each other so that the material can be understood correctly and not just memorized for a moment.

Research results by Harta, et al (2020) conclude that the development of a small scale chemistry practicum module could measure and describe students' ability to predict, observe, and explain chemical phenomena in several experiments. This is reinforced with research by Sanjaya, et al (2017) which concludes that the module based on bounded inquiry lab is effective for improving scientific literacy on the content aspect. The results research by Nursamu, et al (2020) at SMP Negeri 2 Langsa City states that the implementation of practicum related to scientific literacy is rarely carried out. In the science practicum module, the percentage of content aspects is $39 \%$, context aspects are $39 \%$ and process aspects are $40 \%$.

To overcome the problems on background, it is necessary to develop an effective and innovative teaching material in practicum activities in the form of a module based on cooperative learning to form science literate students. Based on the above background, the researchers developed a practicum module with the title "E-Module of Chemistry Practicum Based on Cooperative Learning on Salt Hydrolysis Material to Improve Students's Science Literacy". 


\section{METHOD}

The type of research used is the 4-D development model developed by S. Thiagarajan. This development model includes the define, design, develop and disseminate stages. But this research is limited only to the develop stage with a limited media trial. The object of the limited trial was 24 students of class XII MIA 1 SMAM 10 GKB. This research uses several methods: questionnaire methods, observation methods, and test methods. Several research instruments were used in this study, namely e-module review sheets, e-module validation sheets, pretest-posttest sheets of scientific literacy skills, and student response questionnaires. The research data were sourced from the assessment results of two chemistry lecturers and one chemistry teachers, response questionnaires, and the results of the pretest-posttest students of class XII MIA 1 SMAM 10 GKB.

The chemistry lecturer submitted comments and suggestions for improvements to the practicum e-module through a review sheet. Next, the validation of the practicum e-module is carried out by two lecturers and one teacher through a validation sheet. The assessment score for the e-module is given in the range 1-5 according to the assessment criteria as set out in Table 1.

Table 1. Likert Scale (Riduwan, 2015)

\begin{tabular}{cc}
\hline Criteria & Score \\
\hline Very less & 1 \\
Less & 2 \\
Enough & 3 \\
Good & 4 \\
Very good & 5 \\
\hline
\end{tabular}

The scores obtained are converted to obtain the quality of the developed product. The score conversion is avalaible in Table 2.

Table 2. Score Conversion (Riduwan, 2015)

\begin{tabular}{cc}
\hline Percentage $(\%)$ & Criteria \\
\hline $0-20$ & Not good validity \\
$20.1-40$ & Poor validity \\
$40.1-60$ & Good enough \\
$60.1-80$ & Good validity \\
$80.1-100$ & Very good validity \\
\hline
\end{tabular}

Based on the interpretation in Table 2, the e-module is considered valid if the content validity and construct validity get a percentage of $\geq 61 \%$ with valid criteria. The validated practicum e-module is then revised for improvement and refinement. Next, the e-module practicum was tested to 24 students of class XII MIA 1 SMAM 10 GKB. The purpose of the limited trial is to determine the practicality and effectiveness of the practicum e-module. The practicality of the practicum e-module is determined from the results of the response questionnaires filled out by students after learning. The completed questionnaire is calculated based on the criteria according to the Gautman scale.

Table 3. Gautman Scale (Riduwan \& Sunarto, 2017)

\begin{tabular}{lcc}
\hline Question & Answer & Score \\
\hline Positive & Yes & 1 \\
& No & 0 \\
\hline Negative & Yes & 0 \\
& No & 1 \\
\hline
\end{tabular}


The scores obtained are converted to obtain the quality of the developed product. The score conversion is available in Table 4.

Table 4. Score Conversion (Riduwan, 2015)

$\begin{array}{cc}\text { Percentage (\%) } & \text { Criteria } \\ 0-20 & \text { Not practical } \\ 20.1-40 & \text { Less practical } \\ 40.1-60 & \text { Practical enough } \\ 60.1-80 & \text { Practical } \\ 80.1-100 & \text { Very practical }\end{array}$

The practicum e-module is considered to meet the practicality aspect if it gets a student response percentage of $\geq 61 \%$ with good criteria. The feasibility of the practicum e-module from the aspect of effectiveness is seen from the student's scientific literacy ability. In determining scientific literacy ability, it is done by analyzing the student's pre-test and posttest result. The scientific literacy assessment of students is carried out after students use the developed practicum e-module. To process the data in this study used the SPSS application with a significance level of 5\%. Pre-test and post-test score data were analyzed using the data normality test with the Saphiro Wilk test (Razali \& Wah, 2011). For data with normal distribution, the resultant significance value is more than 0.05. If the data is normally distributed, then we use paired sample t-test to test the hypothesis. If the data are not normally distributed, then we use nonparametric statistics, namely the Wilcoxon test (Sudjana, 2009).

\section{RESULTS AND DISCUSSION}

This study obtained data about the feasibility of the practicum e-module consisting of validity, practicality, and effectiveness. This practicum e-module was developed using the 4D method which consists of the following stages:

\section{Define stage}

This stage contains an analysis of needs, competencies, students, and assignments (Ibrahim, 2001). The pre-research was conducted by distribution scientific literacy tests to students and interviews with chemistry teachers. From the results of the pre-research, we can conclude that students's scientific literacy skills are still low and there is not enough application of scientific literacy-based questions that encourage students to recognize chemical phenomena in everyday life. In addition, practicum learning cannot always be carried out, especially on salt hydrolysis material. Therefore, students need innovation in learning media in the form of an e-module practicum based on cooperative learning on salt hydrolysis material to improve students' scientific literacy. Scientific literacy ability is something that is very basic, especially for all stakeholders involved in science education (Yuliati, 2017). According to Sanjaya, et al (2017) problems related to environmental phenomena or issues in the module require problem solving through investigation activities, namely practicum activities with scientific procedures. The application of learning activities with the developed module can improve scientific literacy because there is a scientific process in the module.

\section{Design stage}

In this stage produces a design of the developed practicum e-module (Ibrahim, 2001). Figure 1 shows the cover of the developed practicum e-module. The cover section is equipped with relevant images to increase students' interest in learning. The picture is an example of salt compounds in everyday life. The initial part of the e-module contains laboratory regulations, hazard symbols, and a brief description of the salt hydrolysis material. 
Then there are 2 learning activities (KB) in this module. KB 1 contains general questions about salt hydrolysis materials. This activity also covers the literacy domain in content knowledge because it contains knowledge about salt hydrolysis.

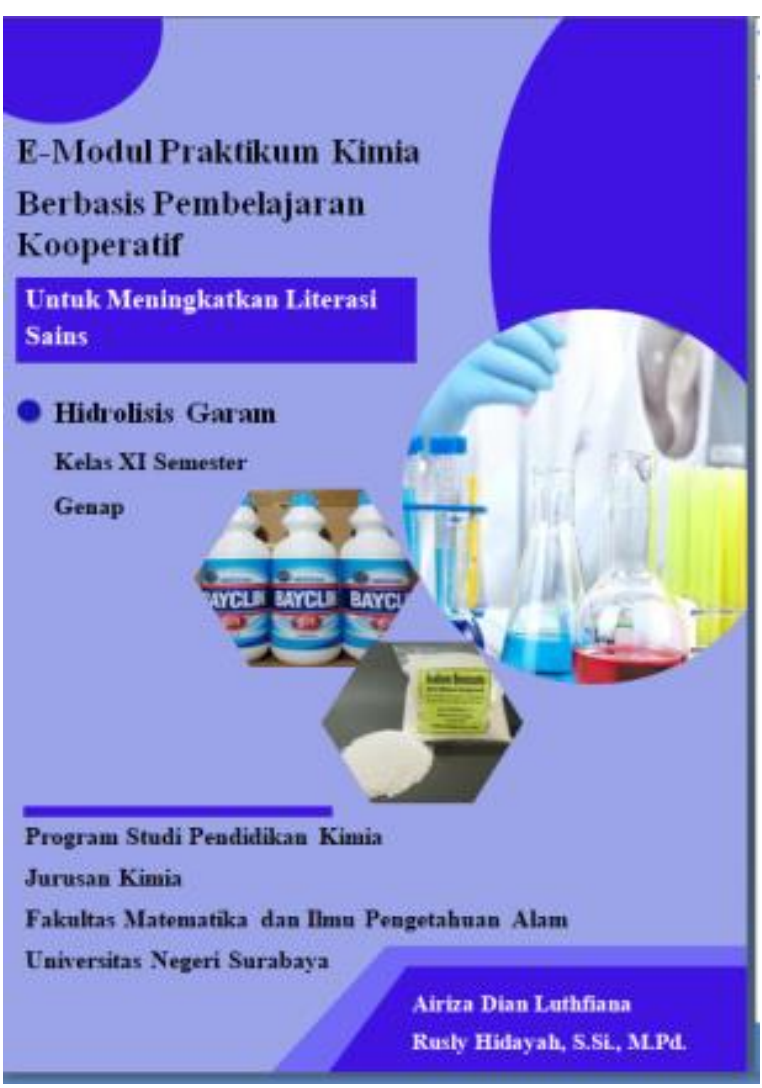

Figure 1. Cover

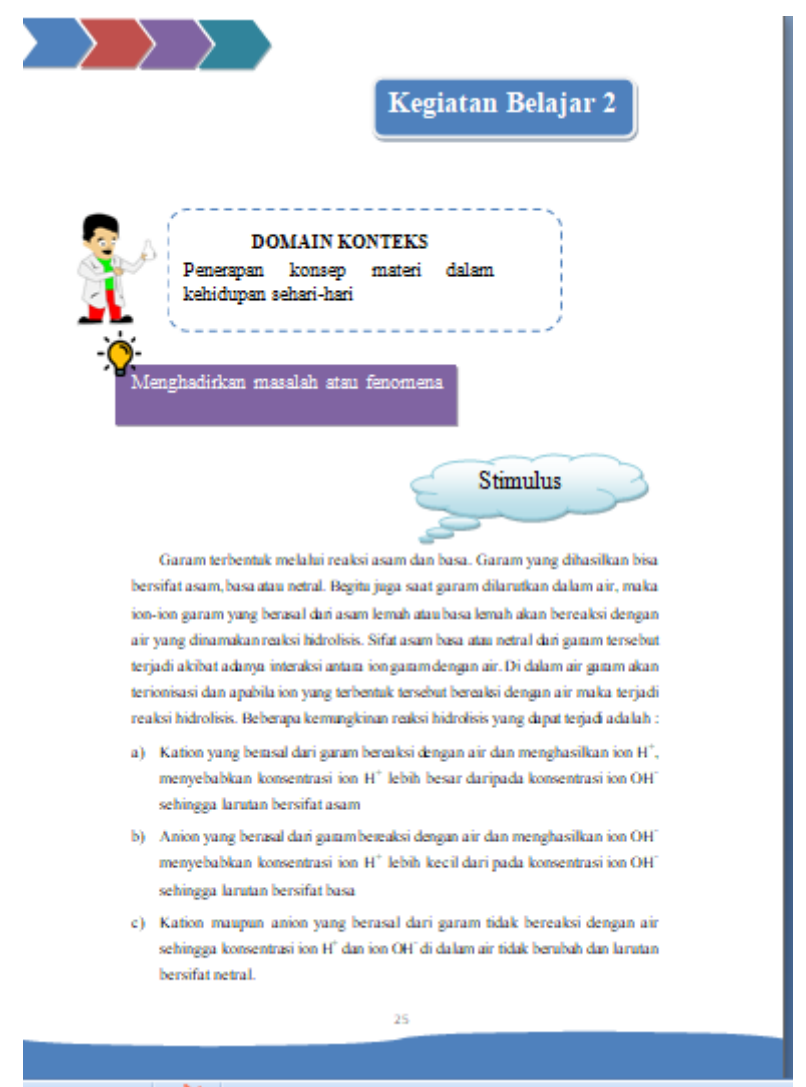

Figure 2. Learning Activity 2

In learning activity 2, the phenomenon and video of the salt hydrolysis experiment were given. This module is in the form of electronics to anticipate online learning so that students can still understand salt hydrolysis experiments through videos. In addition, experimental videos on e-modules can also be applied at home because they use materials around everyday life. KB 2 covers many scientific literacy domains such as context, procedural knowledge, competence, and attitude domains. At the end of each learning activity there is an answer key for each question so that students can evaluate their respective abilities independently. Laboratory-based modules are designed to guide students to independently design and conduct their own experiments with little guidance from the teacher. In addition, students are guided to learn independently in finding concepts and studying the material in depth because it was developed through an investigation process (Sanjaya et al., 2017).

\section{Develop stage}

This stage includes review, revision, validation, testing, and data analysis (Ibrahim, 2001). The product in this stage is an e-module that has been revised based on the review results and has gone through a validation process. The results of the e-module review process will be analyzed quantitatively in order to obtain suggestions for improving the e-module. At this stage, conclusions will also be drawn about the feasibility of the developed e-module where the feasibility is reviewed from the aspects of validity, practicality, and effectiveness.

\section{Validity}

The validity of this e-module is viewed from the content and construct validity using a validation sheet instrument. The construct validity includes aspects of language, presentation, 
and graphics. Then the validity was analyzed and the average percentage is generated in Table 5.

Table 5. E-modul Validation Result

\begin{tabular}{ccc}
\hline Aspect & Percentage (\%) & Category \\
\hline Content & 81.37 & Very good validity \\
Graphic & 82.66 & Very good validity \\
Presentation & 80.66 & Good validity \\
Language & 83.33 & Very good validity \\
\hline
\end{tabular}

Based on Table 5 , the content validity aspect obtained a very valid category with a percentage of $81.37 \%$. This shows that the salt hydrolysis material in the practicum e-module is in accordance with the 2013 curriculum, the core competencies and basic competencies. The images on the e-module are also in accordance with the correct facts and concepts. The phenomena used have a logical relationship with the facts and concepts of salt hydrolysis material. The activities contained in the practicum e-module are student-centered to involves students's activeness. In addition, the questions and phenomena in the e-module train students' scientific literacy skills.

There are three aspects of construct validity: the feasibility of presentation, language, and graphics. The validity of presentation, language, and graphics aims to produce a logical and consistent design, this supports the quality of the resulting e-module. The developed emodule obtained an average percentage of $80.66 \%$ in the presentation aspect and was categorized as valid. Cover represents the contents of the e-module because the image used is an example of salt hydrolysis. The phenomenon in the e-module practicum is able to arouse students' curiosity. The presentation of e-modules is arranged systematically starting from the description of the material, questions about salt hydrolysis, the process of identifying problems, formulating problems and making hypotheses, making workflows, analyzing data, making conclusions and self-evaluation.

The second aspect of construct validity is the language aspect which gets $83.33 \%$ and is categorized as very valid. The sentences used are well structured so that students are easy to understand and there are no misconceptions. The writing of every word used in the e-module is adjusted to the correct Indonesian grammar rules. This is in line with the guidelines for the preparation of teaching materials that must pay attention to the language component, such as compliance with Indonesian language rules, legibility, clear information, effective and efficient use of language (Depdiknas, 2008) .

The construct validity of the graphic aspect obtained a value of $82.66 \%$ which means that the practicum e-module can be said to be very valid. This shows that the e-module design is attractive so that students can learn it easily, the use of fonts (type and size of writing) makes it easier for readers to use the e-module practicum, the background of the e-module practicum is in accordance with the color and writing and the terms, symbols and formulas are written well.

This is in line with research by Nursamsu, et al (2020) which states that the science practicum module which is analyzed based on three categories has a percentage value of $78 \%$ with a valid category, so that the practicum module is declared feasible to be used as a practicum guide (Nursamsu et al., 2020). According to Wahono (2006), a good learning media includes several aspects of assessment : (1) aspects of the substance of the material; (2) media design aspects; (3) general aspects (language, creative, innovative, communicative, and superior). This is in accordance with the opinion by Amir, et al (2016) which states that the developed teaching materials must be accurate, means that they are in accordance with scientific truth and are up-to-date. Relevant to the opinion by Sari (2017), which states that a good teaching material must present a description of the competencies that will be achieved 
by students. The developed teaching materials need to provide information on the competencies that must be mastered by students and the benefits of their application.

\section{Practicality}

The practicality of the practicum e-module is assessed from the response questionnaire and student activity sheets. The response questionnaire consists of questions using the checklist method and there are two answer choices, namely yes and no. The practical emodule is said to be practical if the average response questionnaire results reach a percentage of $\geq 61 \%$. Students are given a response questionnaire containing 15 questions. The 15 questions cover 4 aspects, namely content, graphics, presentation and language. The results of student responses to the practicum e-module is available in Table 6.

Table 6. Student Respon Result

\begin{tabular}{ccc}
\hline Aspect & Percentage $\mathbf{( \% )}$ & Category \\
\hline Content & 87.33 & Very practical \\
Graphic & 97.50 & Very practical \\
Presentation & 86.78 & Very practical \\
Language & 97.52 & Very practical \\
\hline
\end{tabular}

Based on the table 6, we can see that the presentation criteria get the lowest percentage, which is $86.78 \%$. This shows some students feel that there is no increase in enthusiasm, learning insight, and activeness with the e-module practicum. Content criteria get a percentage of $87.33 \%$. The content criteria include several statements, relating to the increasing knowledge about salt hydrolysis, relating the material to everyday life, relating problems scientifically, interpreting data scientifically and communicating data scientifically.

The next aspect is the language, with a percentage of $97.52 \%$. The language and writing used in the practicum e-module are easily understood by students so that it does not cause ambiguity. The fourth criterion is graphics, with a percentage of $97.50 \%$. The color combination in the practicum e-module media is interesting for students, and the tools on the media are easy for students to use.

All aspects of the student response questionnaire including content criteria, language criteria, presentation criteria, and graphic criteria are an integral part of developing practicum e-module based on cooperative learning that are feasible, practical and interesting for students because they have a percentage of $\geq 61 \%$. Positive student responses due to the use of practicum e-modules encourage students to discuss with their friends about phenomena and experiments on salt hydrolysis and make it easier for students to analyze because it is done in groups so that there is an exchange of ideas, opinions or knowledge.

The student activity observation sheet contains the questions in the observation table. The table is filled with the checklist method and there are two answer choices, namely yes and no. Student activities have very practical criteria, because it has an average percentage of $100 \%$ or it can be said that all activities are carried out. Activities in this study include participating in learning enthusiastically, reading and observing the application of concepts in everyday life, discussing with groups or asking questions with other students, identifying questions in e-modules related to the phenomena presented, observing experimental videos carefully and thoroughly, writing and analyzing data from observations, answer questions related to scientific attitudes. This shows that the activities carried out by students are in accordance with the learning activity plans made by the teacher. Figure 3 is the result of limited trial activity. 


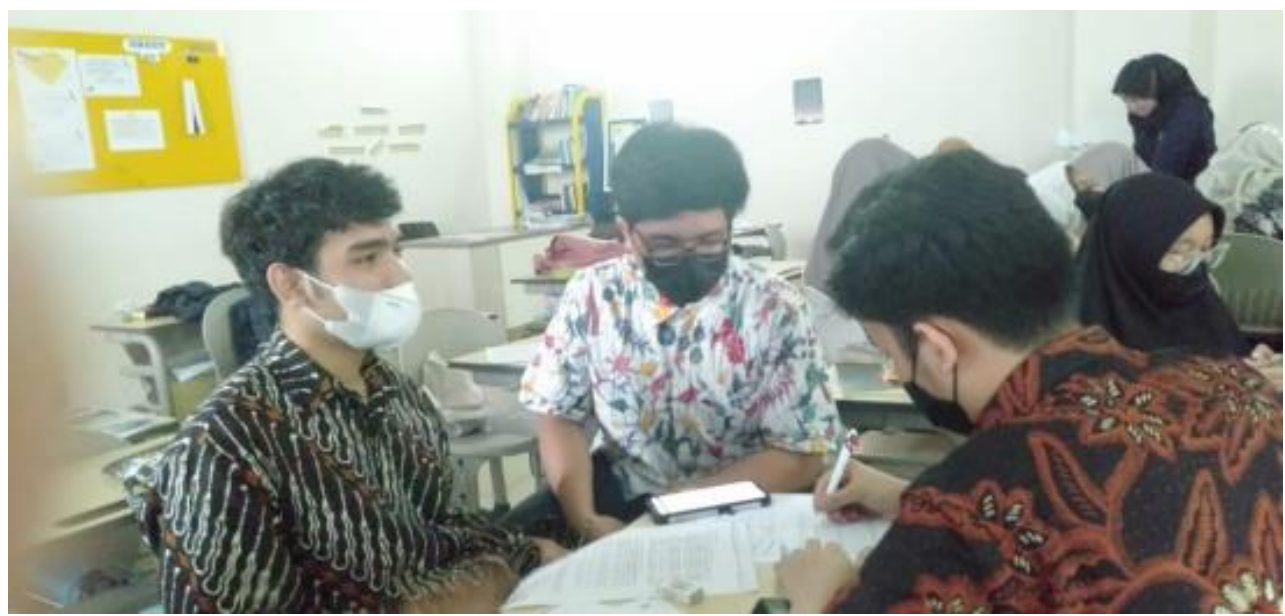

Figure 3. Limitied Trial Activity

Innovation or development in learning media is very important because the media is easily adapted to the times. The research results by Harefa, et al (2019) show that students' responses to chemistry e-module practicum are very high. In the presentation aspect, it gets a percentage of $3.96 \%$, the content aspect is $3.72 \%$ and the language aspect is $3.68 \%$ so that the practicum module gets a very practical category. Students are very interested in digital integrated modules because it suitable with the industry 4.0 era. The research results by Arifani, et al (2021) also show that student responses to the chemistry practicum based on computational chemistry on acid-base materials obtained a percentage of $85 \%$ so that it is included in the very practical category. In addition, the research result by Rahmadani, et al (2018), concludes that teaching materials based on the STAD cooperative model with the guided discovery method are practical, because the average of all components in observing the implementation of teaching materials is 1.89 in the fully implemented category and the results of student responses are $100 \%$ in the positive category.

\section{Effectiveness}

Pre-test and post-test activities were carried out to measure the effectiveness of the emodule. Before learning, pre-test questions are given to students and they do post-test after learning is complete. Twenty choice questions are tested to determine scientific literacy skills based on three domains that refer to PISA 2018, namely the context domain, the knowledge domain and the competence domain. The example of context domain questions is applying the salt hydrolysis concept in everyday life, that is bleaching (sodium hypochlorite) and washing soda (sodium carbonate). The sample question in the content knowledge domain is given four examples of salt solutions, then students are asked to determine which solution has the highest $\mathrm{pH}$. While the sample questions in the competency domain contain a phenomena about three bottles of solution that have no name, then students are asked to determine the name of the appropriate solution in the bottle based on the characteristics of the solution.

The analysis of the results was carried out through a non-parametric test, that is the Wilcoxon Signed Rank Test. The basis for making decisions from the Wilcoxon test is if the Asymp value. Sig. (2-tailed) $<0.05$, then $\mathrm{H}_{0}$ is rejected, but if the value of Asymp. Sig (2tailed) $>0.05$, then $\mathrm{H}_{0}$ is accepted (Ghozali, 2016).

$H_{0}=$ There is no effect on the result of students' scientific literacy test after learning activities is carried out by using the developed practicum e-module.

$H a=$ There is an effect on the result of students' scientific literacy test after learning activities is carried out by using the developed practicum e-module.

We can see the ranks of the cognitive tests (pre-test and post-test) in Table 7. 
Table 7. Wilcoxon Signed-Rank Test Results

\begin{tabular}{clrrr}
\hline & N & Mean Rank & Sum of Ranks \\
\hline Pos test - Pre test Negative Ranks & $0^{\mathrm{a}}$ & .00 & .00 \\
Positive Ranks & $24^{\mathrm{b}}$ & 12.50 & 300.00 \\
Ties & $0^{\mathrm{c}}$ & & \\
Total & 24 & & \\
\hline
\end{tabular}

Based on the table 7 , the negative ranks data shows that there is no decrease in the students' scores from pretest to posttest. Based on the positive ranks data, it shows that the score of students from pretest to posttest which has increased there are 24 students. The ties data shows, it shows that there are no students who get a fixed score from pre-test to posttest. We can see the results of the Wilcoxon test in Table 8.

Table 8. Statistic Test

\begin{tabular}{lrr}
\hline & Pos test - Pre test \\
\hline$Z$ & $-4.295^{\mathrm{b}}$ \\
Asymp. Sig. (2-tailed) & .000 \\
\hline
\end{tabular}

Based on table 8, it can be seen that the value of Asymp. Sig. (2-tailed) of 0.000 and the value is $<0.05$, so we can conclude that $\mathrm{H}_{0}$ is rejected (there is an effect on the results of student's scientific literacy test after learning is carried out using the e-module.). Based on the value of students' scientific literacy skills through the post test, it shows that the ability in the content knowledge aspect is $71.37 \%$, the largest percentage than the other two aspects, the competence aspect gets a percentage of $64.06 \%$ and the context aspect gets a percentage of $59.37 \%$.

This is in line with research by Sumarn, et al (2021) which shows that the results of students' scientific literacy after learning the excretory system using practicum guidelines have an average value of 70.06 which is included in the high category. Student's scientific literacy is increasing and measured based on two aspects: the competence aspect and the knowledge aspect. The skills in competence aspect include explaining phenomena scientifically, evaluating and designing scientific questions, interpreting data and evidence. Students' scientific literacy skills in the domains of content, procedural, and epistermic knowledges are also increasing. Science has an increasingly high role in supporting science and technology. It is very important for students to have high scientific literacy skills so that they have a responsive and critical attitude towards various scientific issues that develop in society. Therefore, various efforts to improve the mastery of scientific literacy are needed (Mujizah et al., 2020).

\section{CONCLUSION}

The validity of the practicum e-module was assessed based on the aspects of content, language, presentation, and graphics, getting an average percentage of $81.37 \%, 83.33 \%$, $80.66 \%$ and $82.66 \%$ with very valid and valid criteria. The practicality of the practicum emodule is assessed based on student responses and observations of student activities. Student responses in terms of content, language, presentation and graphic aspects obtained an average percentage of $87.33 \%, 97.52 \%, 86.78 \%$ and $97.50 \%$ with very practical criteria. Student activities get very practical criteria because the activity has an average percentage of $100 \%$. This shows that all activities carried out by students are in accordance with the learning activity plans made by the teacher. The effectiveness of the practicum e-module is assessed from the results of the pretest and posttest. Wilcoxon test results get the Asymp value. Sig. (2-tailed) of $0.000\left(\mathrm{H}_{0}\right.$ is rejected), it means that there is an effect on the results of the student's scientific literacy test after learning is carried out using the developed practicum emodule. 


\section{RECOMMENDATION}

E-module of chemistry practicum can help teachers, especially when learning online. Students can observe the video of the salt hydrolysis experiment on the module and if possible it would be better for students to practice directly based on the experimental video listed in the e-module. Practicum e-module help students to learn independently but still need supervision and assistance from the teacher. Some questions and phenomena in the e-module can train students' scientific literacy.

\section{REFERENCES}

Amir, A., Soendjoto, M. A., \& Dharmono, D. (2016). Validitas bahan ajar pengayaan IPA SMP/MTs berbasis riset perilaku makan monyet ekor panjang (Macaca fascicularis, Raffles) di hutan karet. Proceeding Biology Education Conference: Biology, Science, Enviromental, and Learning, 58-62.

Arifani, D. Y. M., Savalas, L. R. T., Ananto, A. D., Junaidi, E. M. P. K. B. K. K. P. M. A. B., \& Hadisaputra, S. (2021). Pengembangan Modul Praktikum Kimia Berbasis Kimia Komputasi Pada Materi Asam Basa. Prosiding SAINTEK LPPM Universitas Mataram.

Choi, K., Lee, H., Shin, N., Kim, S.-W., \& Krajcik, J. (2011). Re-Conceptualization of Scientific Literacy in South Korea for the 21st Century. Journal Of Research In Science Teaching, 48(4), 670-697.

Depdiknas. (2008). Panduan Pengembangan Bahan Ajar. Departemen Pendidikan Nasional.

Djamarah, S. B., \& Zain, A. (2006). Strategi Belajar Mengajar. Rineka Cipta.

Febriani, G., Marfu'ah, S., \& Joharmawan, R. (2018). Identifikasi Konsep Sukar, Kesalahan Konsep, Dan Faktor-Faktor Penyebab Kesulitan Belajar Hidrolisis Garam Siswa Salah Satu SMA Blitar. Jurnal Pembelajaran Kimia, 3(2), 35-43.

Ghozali, I. (2016). Aplikasi Analisis Multivariate dengan Program IBM SPSS 23 (8th ed.). Universitas Diponegoro.

Harefa, N., Namsari, \& Purba. (2019). The Development Of Chemistry Practicum Emodule Based On Simple-Practice. Jurnal Pendidikan Kimia, 11(3), 107-1.

Harta, J., Listyarini, R. V., Pamenang, F. D. N., Wijayanti, L. W., \& Lee, W. (2020). Developing Small Scale Chemistry Practicum Module To Identify Students' Ability In Predict Observe-Explain (Poe) Implementation. JKPK (Jurnal Kimia Dan Pendidikan Kimia), 5(1), 91-99.

Hayati, S. (2017). Belajar dan Pembelajaran Berbasis Cooperative Learning. Graha Cendekia.

Hidayah, R., \& Luthfi, A. (2017). Training Science Process Skills Using Virtual Laboratory On Learning Acid, Base, And Salt. JCER (Journal of Chemistry Education Research), 1(1).

Ibrahim, I. (2001). Pengembangan Perangkat Pembelajaran. Departemen Pendidikan Nasional.

Kasih, A. P. (2020). Nilai PISA Siswa Indonesia Rendah, Nadiem Siapkan 5 Strategi Ini. https://amp.kompas.com/edukasi/read/2020/04/05/154418571/nilai-pisa-siswaindonesia-rendah-nadiem-siapkan-5-strategi-ini.

Kim, D. (2018). A Study On The Influence Of Korean Middle School Students’ Relationship Through Science Class Applying Stad Cooperative Learning. Journal of Technology and Science Education.

Merta, I. W., Artayasa, I. P., Kusmiyati, Lestari, N., \& Setiadi, D. (2020). Profil Literasi Sains Dan Model Pembelajaran Dapat Meningkatkan Kemampuan Literasi Sains. J. Pijar MIPA, 15(3), 223-228.

Mohandas, R. (2014). Kurikulum 13 Pedoman Guru Mata Pelajaran Kimia. Pusat Kurikulum dan Perbukuan. 
Mujizah, R., Wati, M., \& Mahtari, S. (2020). Pengembangan E-modul Menggunakan Aplikasi Exe-Learning untuk Melatih Literasi Sains. Jurnal Ilmiah Pendidikan Fisika, 4(2), 89-98.

Noviana, E., \& Huda, M. N. (2020). Penerapan Model Pembelajaran Kooperatif Tipe Stad Untuk Meningkatkan Hasil Belajar Pkn Siswa Kelas Iv Sd Negeri 79 Pekanbaru. Jurnal Pendidikan Guru Sekolah Dasar Fakultas Keguruan Dan Ilmu Pendidikan Universitas Riau, 7(2).

Nursamsu, N., Mustika, D., Nafaida, R., \& Manurung, N. (2020). Analisis Kelayakan Dan Kepraktisan Modul Praktikum Berbasis Literasi Sains Untuk Pembelajaran Ipa. JIPI (Jurnal IPA Dan Pembelajaran IPA), 4(1), 29-40.

Purwanto, A., Pramono, R., Asbari, M., Santoso, Priyono Budi Mayesti, L., Wijayanti, Hyun, C. C., \& Putri, R. S. (2020). Studi Eksploratif Dampak Pandemi COVID-19 Terhadap Proses Pembelajaran Online di Sekolah Dasar. EduPsyCouns Journal, 2(1).

Rahmadani, Y., Tayeb, T., \& Baharuddin, B. (2018). Modul Matematika Berbasis Model Kooperatif Tipe Stad Dengan Metode Penemuan Terbimbing Pada Pokok Bahasan Teorema Phytagoras. Lentera Pendidikan, 21(1), 23-32.

Razali, N. M., \& Wah, Y. B. (2011). Power comparisons of Shapiro-Wilk, KolmogorovSmirnov, Lilliefors and Anderson-Darling tests. Journal of Statistical Modeling and Analytics, 2(1), 21-33.

Riduwan, R. (2015). Skala Pengukuran Variabel-Variabel Penelitian. Alfabeta.

Riduwan, \& Sunarto. (2017). Pengantar Statistika untuk Penelitian: Pendidikan, Sosial, Komunikasi, Ekonomi, dan Bisnis (Alfabeta (ed.)).

Rosmalinda, D., Rusdi, M., \& Hariyadi, B. (2013). Pengembangan Modul Praktikum Kimia SMA Berbasis PBL(Problem Based Learning). Edu-Sains Volume, 2(2).

Sanjaya, R. W. K., Maridi, \& Suciati. (2017). Pengembangan Modul Berbasis Bounded Inquiry Lab Untuk Meningkatkan Literasi Sains Dimensi Konten Pada Materi Sistem Pencernaan Kelas XI. Jurnal Penelitian Pendidikan Biologi, 1(1), 19-32.

Sari, R. T. (2017). Uji validitas modul pembelajaran Biologi pada materi Sistem Reproduksi Manusia melalui pendekatan Konstruktivisme untuk kelas IX Smp. Scientiae Educatia: Jurnal Pendidikan Sains, 6(1), 22-26.

Sudjana, S. (2009). Metode Statistika. Tarsito.

Sumarn, R., Soesilawati, S. A., \& Sanjaya, Y. (2021). Literasi sains dan penguasaan konsep siswa setelah pembelajaran sistem ekskresi menggunakan pedoman praktikum berbasis literasi sains. Indonesian Journal of Biology Education, 4(1), 32-36.

Vogelzang, J., Admiraal, W. F., \& Driel, J. H. van. (2020). Effects Of Scrum Methodology On Students' Critical Scientific Literacy: The Case Of Green Chemistry. Chemistry Education Research and Practice.

Wahono, romi satria. (2006). Aspek dan kriteria penilaian media pembelajaran.

Waris, A., Darsikin, D., \& Nurjannah, N. (2017). Pengembangan alat praktikum sederhana konsep listrik magnet untuk siswa smp daerah terpencil. JPFT (Jurnal Pendidikan FisikaT Adulako Online), 3(2), 1-7.

Wibowo, E. (2018). Pengembangan Bahan Ajar E-Modul Dengan Menggunakan Aplikasi Kvisoft Flipbook Maker. Universitas Islam Negeri (Uin) Raden Intan Lampung.

Wiyono, G. P. (2011). Identifikasi Konsep Sukar dan Kesalahan Konsep Asam-Basa Bronsted-Lowry pada Siswa Kelas XI SMA Negeri 1 Malang Tahun Ajaran 2010/2011. Universitas Negeri Malang.

Yulando, S. (2019). Electronic Module Design and Development: An Interactive Learning. American Journal of Educational Research, 7(10), 694-698.

Yuliati, Y. (2017). Literasi Sains Dalam Pembelajaran IPA. Jurnal Cakrawala Pendas, 3(2), $21-28$. 